\title{
Synthesis, Crystal Structure and Spectroscopic Studies of 1-(p- Bromphenyl)-3,5 Diphenylformazan
}

\author{
Tuncay Tunç $c^{\mathrm{a}, *}$ and Leyla Tatar Yıldırım ${ }^{\mathrm{b}}$ \\ ${ }^{a}$ Science Education Department, Faculty of Education, Aksaray University, Aksaray, Turkey \\ ${ }^{b}$ Physics Engineering Department, Faculty of Enginering, Hacettepe University, Ankara, Turkey
}

\begin{abstract}
In this study, novel 1-substituted-phenyl-3,5-diphenylformazans were synhesized with $-\mathrm{Br}$ group at p-positions. Their structures were elucidated by elemental analyses, UV-vis and IR spectroscopy and X-ray single crystal structure determination. Their UV-vis spectra indicated that their $\lambda_{\max }$ showed a shift amount of which was dependent upon the position of the substituent on the ring. The title compound, 1-(p-bromphenyl)-3,5 diphenylformazan, crystallizes in the orthorombic P bca space group, with $a=7.9526(9) \AA, b=18.611(2) \AA, c=23.099(2) \AA$. The final cycle of refinement was converged to $\mathrm{R}=0.0703$. The big part of the molecule is coplanar. The molecular conformation is maintained by an intramolecular $\mathrm{N}-\mathrm{H}^{\cdots} \mathrm{N}$ hydrogen bond.
\end{abstract}

Keywords: Formazan, X-ray, organic compound, crystal structure.

\section{INTRODUCTION}

Formazans are compounds containing the characteristic azohydrazone group $(-\mathrm{N}=\mathrm{N}-\mathrm{C}=\mathrm{N}-\mathrm{NH}-)$, which is a good carrier of $\pi$-bonding and chelating properties. They are widely used as dyes, as ligands in complex formation reactions, and as analytical reagents, where their deep colour makes them good indicators of redox reactions $[1,2]$. Formazans form salts and complexes with several metal ions, and especially the transition metal ions. Their derivatives with electron donating and withdrawing group attached to 1,3,5- phenyl ring were synthesized and the effects of substituents on the absorption $\lambda_{\max }$ values were examined. They are also biologically active and there is much interest in their biological applications [3]. Various 1 and 3-substituted formazans were synthesized and, the effect of substituents evaluated by using UV-vis and IR spectra [4, 5]. The biological activity of formazan makes the knowledge of its oxidation potentials and possible mechanisms very important. In the present study, a noval formazan complex with substituent on 1-phenyl ring has been synthesized and its structure was determined using the X-ray diffraction method and characterized with spectroscopic techniques. The structure of formazan complex molecule is given in Fig. (1).

\section{MATERIALS AND METHODOLOGY}

\section{General Procedures and Materials}

All starting reagents and solvents were purchased from Merck, Sigma-Aldrich Chemical Co. and used without further purification. IR spectrum was recorded on a MATTSON 1000 FT-IR spectrophotometer with range $4000-625 \mathrm{~cm}^{-1}$

\footnotetext{
*Address correspondence to this author at the Science Education Department, Faculty of Education, Aksaray University, Aksaray, Turkey;

Tel: +90 506 5057102; Fax: +90 382 2801180;

E-mail: tctunc@gmail.com
}

using $\mathrm{KBr}$ pellets. Absorption spectra were obtained with UNICAM UV2-100 UV-vis spectrophotometer using $1 \mathrm{~cm}$ quartz cells in $10^{-4} \mathrm{~mol}^{-1}$ methanol in the range of 192.2$600 \mathrm{~nm}$. Elemental analyses for $(\mathrm{C}, \mathrm{H}, \mathrm{N})$ were performed using a LECO CHNS 932 elemental analyzer.

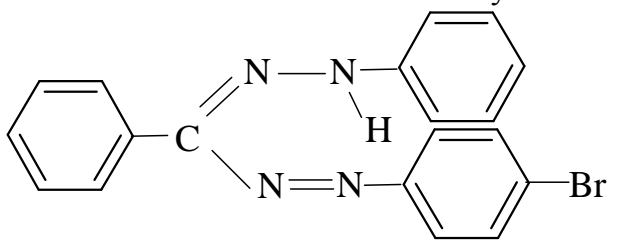

Fig. (1). Chemical diagram of 1-(p-bromphenyl)-3,5 diphenylformazan.

\section{Synthesis of 1-(p-Bromphenyl)-3,5 Diphenylformazan}

For the synthesis, dissolved Benzaldehyde ( $2.12 \mathrm{~g}, 0.02$ $\mathrm{mol})$ in $12.5 \mathrm{ml}$ methanol was gradually added to phenylhydrazine $(2.16 \mathrm{~g}, 0.02 \mathrm{~mol})$ with constant stirring at $\mathrm{pH}$ 5-6. The procedure was completed in $45 \mathrm{~min}$. The resulting white hydrazone was left on the bench over night and was then filtered and recrystallized from methanol. The benzaldehyde phenylhydrazone (1.06 g, $0.01 \mathrm{~mol})$ was dissolved in methanol $(50 \mathrm{ml})$. By constant stirring under reflux and buffer solution (prepared as before). In another flask, p-brombenzendiazonium chloride solution was prepared using $\mathrm{p}$ bromaniline $(1.7203 \mathrm{~g}, 0.01 \mathrm{~mol})$ concentrated $\mathrm{HCl}(2.5 \mathrm{ml})$ and sodium nitrite $(0.75 \mathrm{~g})$ at $0-5^{\circ} \mathrm{C}$. This solution was added to the benzaldehyde phenylhydrazone solutions dropwise with constant stirring to form compound. The solution stirred to $2 \mathrm{~h}$ at the same temperature and kept in a cupboard for 2 days. Dye was filtered and then washed water and methanol. The compound was recrystallised from diclormethane. Red colored crystal; m.p $189^{\circ} \mathrm{C}$; yield $74 \%$. Analysis calculated for $\mathrm{C}_{19} \mathrm{H}_{15} \mathrm{BrN}_{4}(\%)$ : C, 60.16; H, 3.96; $\mathrm{Br}, 21.11 ; \mathrm{N}, 14.76$. Found (\%): C, 60.12; H, 3.90; Br, 21.20; N, 14.79. 


\section{RESULTS AND DISCUSSION}

\section{IR and UV-VIS Spectra of 1-(p-Bromphenyl)-3,5 Diphenylformazan}

The most characteristics bands of the complex is summarized in Table 1 . As seen from Table $1, v(\mathrm{C}=\mathrm{N})$ bands at $1520-1500 \mathrm{~cm}^{-1}$ and $v(\mathrm{~N}=\mathrm{N})$ bands at $1450-1410 \mathrm{~cm}^{-1}$ were observed in the complex. These results are in agreement with literature $[4,5]$. The $v(\mathrm{~N}-\mathrm{N})$ valans vibration bands observed in the region 1080,1055 and $1030 \mathrm{~cm}^{-1}$. Other aromatic $v(\mathrm{C}$ $\mathrm{H}), v(\mathrm{C}=\mathrm{C}), v(\mathrm{CNNC})$ skeleton stretching bands in the compound were observed in their expecting regions. Table 2 list all peaks observed in the UV-vis spectra of 1-(pbromphenyl)-3,5 diphenylformazan and the values of literature of 1, 3,5 triphenylformazan at same solvent [6]. The chemical shift values $\left(\Delta \lambda_{\max }\right)$ were compared by taking the difference between the $\lambda_{\max 1}$ values of the $p$-Br substituted formazan with the $\lambda_{\max }$ value of TPF in this study. The peaks listed as $\lambda_{\max 1}$ in Table 2 are the broad peaks which are characteristic of the formazan skeleton. They are generally observed at $410-500 \mathrm{~nm}$ depending upon structure. These peaks are due to $\pi-\pi^{*}$ electronic transitions in the formazan skeleton. The sharp $\lambda_{\max 2}$ peaks which appear at 300-350 $\mathrm{nm}$ correspond to $\mathrm{n}-\pi^{*}$ electronic transitions of the $-\mathrm{N}=\mathrm{N}-$ group. The $\lambda_{\max 3}$ peaks observed at $210-300 \mathrm{~nm}$ originate from $\mathrm{n}-\pi^{*}$ transitions of $-\mathrm{C}=\mathrm{N}-$ groups. As seen from Table 2, the $\lambda_{\max 1}$ value of TPF at $483 \mathrm{~nm}$, shifts to 489 $\mathrm{nm}$ when the 1-phenyl ring is substituted with $\mathrm{a}-\mathrm{Br}$ at the $p$-positions.

\section{Description of the Crystal Structure of 1-(p- Bromphenyl)-3,5 Diphenylformazan}

A needle red crystal with a size of $0.5 \times 0.04 \times 0,04 \mathrm{~mm}$ was used for diffraction experiments. Diffraction measurements were made at room temperature on a Stoe IPDS II CCD X-ray diffractometer using graphite-monochromated $\mathrm{MoK}_{\alpha}$ radiation using w-scan mode [7]. Unit-cell dimensions were determined and refined by using the angular settings of 25 automatically centered reflections in the $1.76<\theta<26$ range. The empirical absorption corrections were applied by the multiscan method via X-RED32 software. Data collection, cell refinement and data reduction performed using STOE X-AREA and STOE X-RED $[7,8]$. The structure was solved by direct methods and refinement using the programs SHELXS97 and SHELXL97, respectively [9] in the WinGX package [10]. The quality of crystals obtained was always poor and this fact may underlie both low proportion of the reflection labelled "observed" at room temperature and fairly high merging index. A full-matrix least-squares refinement on $F^{2}$ converged at $\mathrm{R}=0.0703$. All non-hydrogen atoms were refined anisotropically. Hydrogen atom of the N3 atom is taken from a difference Fourier map and fixed its thermal parameter, while the other hydrogen atoms were in calculated positions using the riding method with $\mathrm{U}_{\text {iso }}(\mathrm{H})=1.2 \mathrm{U}_{\mathrm{eq}}(\mathrm{C})$. Hydrogen bond and molecular packing geometry of the title molecule was calculated with PLATON [11]. The graphical representations of the structure were made with ORTEP [12] (see Fig. 2) and MERCURY [13]. The crystal and instrumental parameters used in the unit cell determination and data collection are summarized in Table $\mathbf{3}$. Selected bond lengths and angles are given in Table 4. ORTEP drawing of the molecule with $20 \%$ probability displacement thermal ellipsoids and atom-labeling scheme are shown in Fig. (2).

\section{CONCLUSION}

The molecule of the title compound has $\mathrm{C}=\mathrm{N}$ and $\mathrm{N}=\mathrm{N}$ double bond [C13-N4=1.324(10), N1-N2=1.300(10) $\AA]$. The exocyclic $\mathrm{C}-\mathrm{C}-\mathrm{N}$ bond angles around the $\mathrm{Cl}$ atom are asymmetrical. The $\mathrm{C} 6-\mathrm{C} 1-\mathrm{N} 1$ angle $\left[111.2(8)^{\circ}\right]$ is significantly smaller than the $\mathrm{C} 2-\mathrm{C} 1-\mathrm{N} 1$ angle $\left[128.2(8)^{\circ}\right]$. C13$\mathrm{N} 2-\mathrm{N} 1 \quad\left[122.7(9)^{\circ}\right]$ and C13-N4-N3 $\left[121.0(8)^{\circ}\right]$ angles around the N2, N4 atoms are almost equal to each other. The aromatic rings in the molecule as expected have usual bond lengths and angles. The title compound has a strong in-

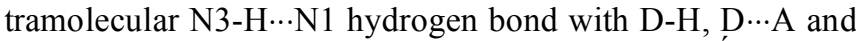
$\mathrm{H} \cdots \mathrm{A}$ distances of $0.96(5), 2.405(11)$ and $1.59(6) \AA$, respectively, and $\mathrm{D}-\mathrm{H}^{\cdots} \mathrm{A}$ angle of $140(8)^{\circ}$ as shown Fig. (3a). This bond turns the molecule in to a chelate structure, which is responsible for its tautomerism. This hydrogen bond possibly influences the relative orientation of the phenyl rings. Tautomerism of $1,3,5$ triphenylformazan was also seen

Table 1. The IR Data of 1-(p-Bromphenyl)-3,5 Diphenylformazan (in $\mathrm{KBr}, \mathrm{cm}^{-1}$ )

\begin{tabular}{|c|c|c|c|c|c|}
\hline Aromatic C-H & Aromatic C=C & $\mathbf{C}=\mathbf{N}$ & $\mathbf{N}=\mathbf{N}$ & N-N Valans Vibration & CNNC Structural Vibration \\
\hline \hline \multirow{2}{*}{3100} & \multirow{2}{*}{1605} & 1520 & 1450 & 1080 & $935-840$ \\
& & 1500 & 1410 & 1055 & \\
& & & & 1030 & \\
\hline
\end{tabular}

Table 2. UV- visible Absorption Maxima of Formazans $\left(\mathrm{CH}_{3} \mathrm{OH}, 10^{-4} \mathrm{~mol} / \mathrm{l}\right)$

\begin{tabular}{|c|c|c|c|c|}
\hline Compound & $\begin{array}{c}\lambda_{\max } \\
(\mathbf{n m})\end{array}$ & $\begin{array}{l}\lambda_{\max 2} \\
(\mathbf{n m})\end{array}$ & $\begin{array}{c}\lambda_{\max 3} \\
(\mathbf{n m})\end{array}$ & $\begin{array}{c}\Delta \boldsymbol{\lambda}_{\max } \\
(\mathbf{n m})\end{array}$ \\
\hline \hline 1,3,5 triphenylformazan (TPF) & 483 & 335 & 298 & - \\
1-(p-bromphenyl)-3,5 diphenylformazan & 489 & 300 & 230 & - \\
& & & 0.23 \\
\hline
\end{tabular}

$\Delta \lambda_{\max }=\lambda_{\max }(\mathrm{TPF})-\lambda_{\max }($ substituted formazan $)$. 


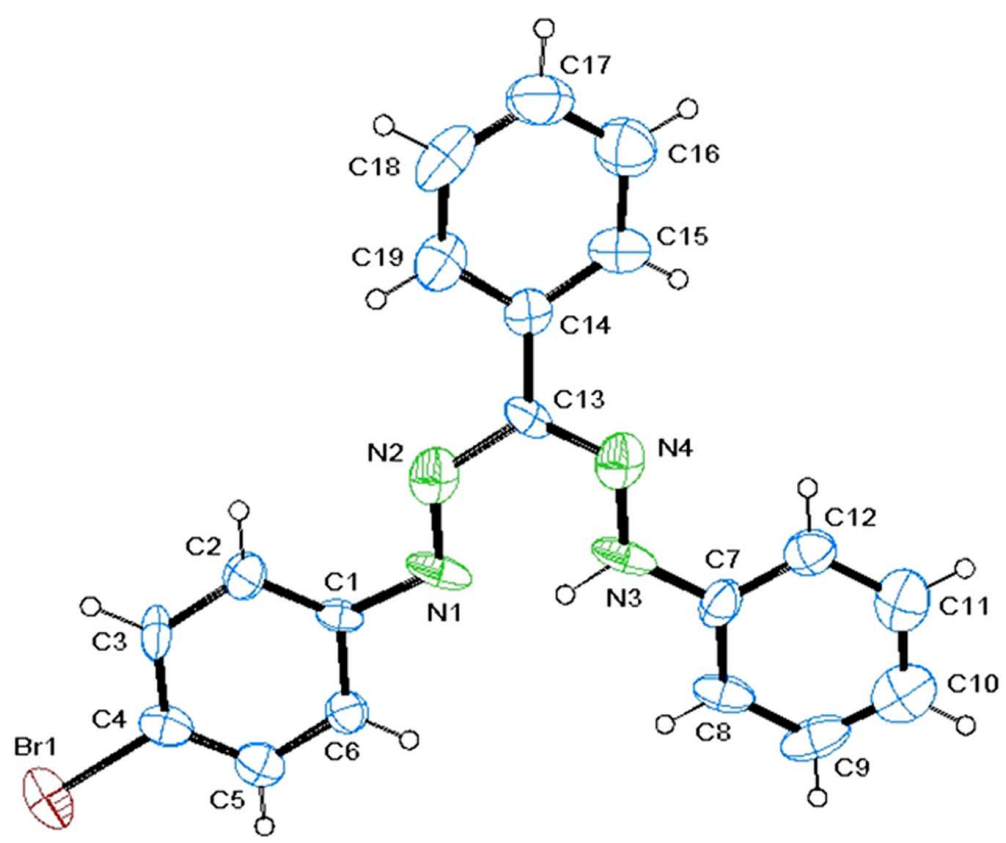

Fig. (2). ORTEP drawing of the title compounds with the atomic numbering scheme. Displacement ellipsoids are drawn at the $30 \%$ probability level.

Table 3. Crystal Data and Structure Refinement Details for Complex

\begin{tabular}{|c|c|}
\hline Formula weight $[\mathrm{g} / \mathrm{mol}]$ & 379.25 \\
\hline Crystal system / space group & orthorhombic / P b c a \\
\hline Unit cell dimensions: $[\AA]$ & $\mathrm{a}=7.9526(9), \mathrm{b}=18.611(2), \mathrm{c}=23.099(3)$ \\
\hline Calculated density $\left[\mathrm{g} / \mathrm{cm}^{3}\right]$ & 1.474 \\
\hline Crystal colour / shape / size $[\mathrm{mm}]$ & Red / needle / $0.50 \times 0.04 \times 0.04$ \\
\hline$F(000)$ & 1536 \\
\hline Absorption coefficient $\left[\mathrm{mm}^{-1}\right]$ & 2.412 \\
\hline$\theta$-range for data collection $\left[{ }^{\circ}\right]$ & $1.76-26.00$ \\
\hline Limiting indices & $0 \leq h \leq 9,0 \leq k \leq 22,0 \leq l \leq 28$ \\
\hline Reflections collected / Unique & $23082 / 3353$ \\
\hline Data / parameters / restraints & $3353 / 220 / 2$ \\
\hline Goodness-of-fit on $F^{2}$ & 0.864 \\
\hline wR & 0.124 \\
\hline
\end{tabular}


Table 4. Selected Bond Lengths and Angles $\left(\AA,^{\circ}\right)$

\begin{tabular}{|c|c|c|c|c|c|}
\hline $\mathrm{Br} 1-\mathrm{C} 4$ & $1.890(8)$ & $\mathrm{N} 1-\mathrm{N} 2-\mathrm{C} 1$ & $110.8(10)$ & $\mathrm{N} 3-\mathrm{C} 7-\mathrm{C} 12$ & $119.0(10)$ \\
\hline $\mathrm{N} 2-\mathrm{C} 13$ & $1.475(11)$ & $\mathrm{N} 3-\mathrm{N} 4-\mathrm{C} 13$ & $121.0(8)$ & $\mathrm{Br} 1-\mathrm{C} 4-\mathrm{C} 3$ & $119.7(8)$ \\
\hline $\mathrm{N} 3-\mathrm{N} 4$ & $1.373(9)$ & $\mathrm{N} 2-\mathrm{C} 13-\mathrm{N} 4$ & 117.1(10) & $\mathrm{Br} 1-\mathrm{C} 4-\mathrm{C} 5$ & $120.5(8)$ \\
\hline $\mathrm{N} 3-\mathrm{H}$ & $0.96(5)$ & $\mathrm{N} 4-\mathrm{C} 13-\mathrm{C} 14$ & $116.1(8)$ & $\mathrm{N} 3-\mathrm{N} 4-\mathrm{C} 13-\mathrm{N} 2$ & $2.6(10)$ \\
\hline $\mathrm{N} 4-\mathrm{C} 13$ & $1.324(10)$ & $\mathrm{N} 3-\mathrm{C} 7-\mathrm{C} 8$ & $120.4(10)$ & $\mathrm{N} 1-\mathrm{N} 2-\mathrm{C} 13-\mathrm{N} 4$ & $1.9(11)$ \\
\hline
\end{tabular}
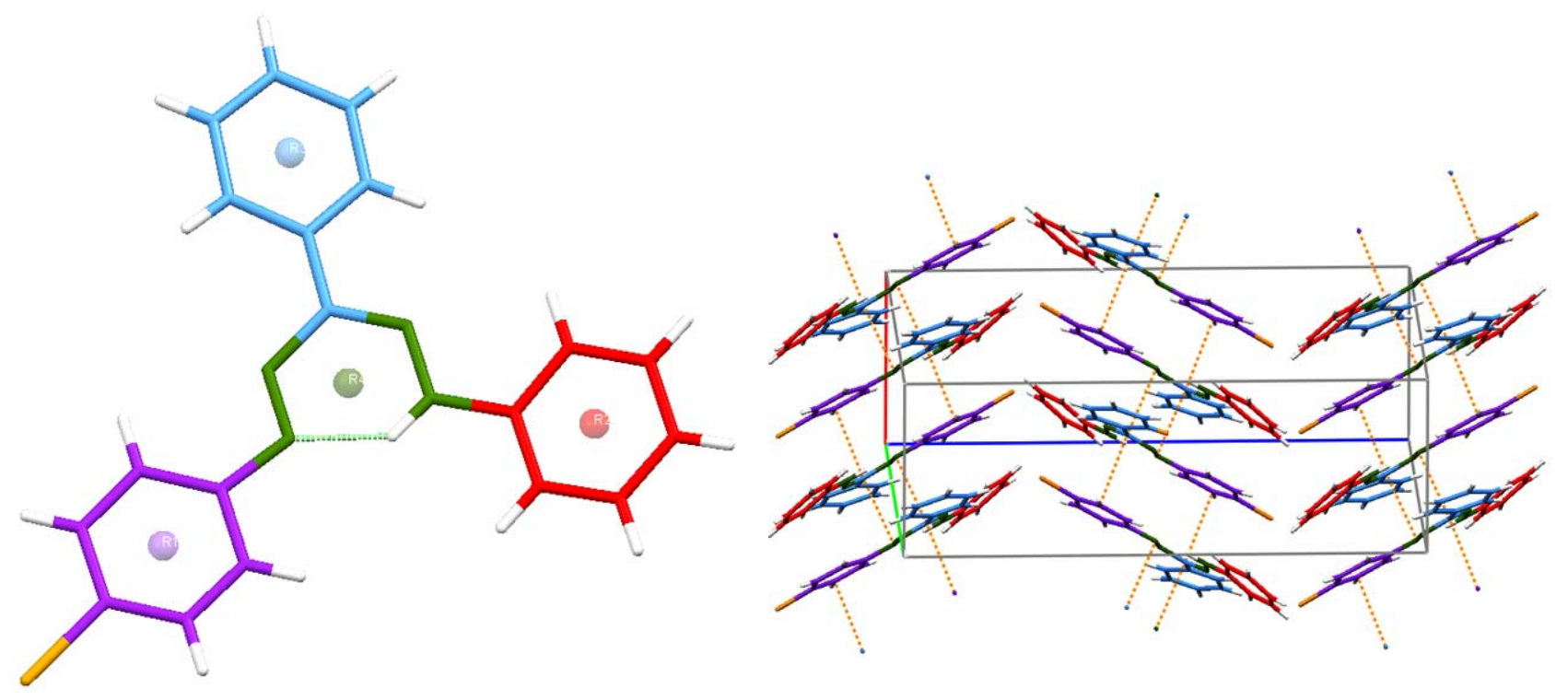

Fig. (3). (a) View of the center of rings in compound, (b) View of the crystal packing.

before in spectral investigation [3]. The molecule has almost planar conformation. In the asymmetric unit of the molecule, the dihedral angle between the least square planes of the phenyl rings $\mathrm{R} 1$ [C1-C2-C3-C4-C5-C6], R2 [C7-C8-C9C10-C11-C12], R3 [C14-C15-C16-C17-C18-C19] and the chelate ring R4 [N1-N2-C13-N4-N3-H] are given in Table 5 (see Fig. 3a). In the crystal structure, the shortest intermolecular $\pi$-ring distance of $4.135(6) \AA$ is observed between R1 and $\mathrm{R} 3^{\mathrm{i}}$ (symmetry codes $\mathrm{i}: 1-\mathrm{x},-\mathrm{y},-\mathrm{z}$ ). In addition to this, there exist weak intermolecular interactions between N1$\mathrm{C} 13^{\mathrm{i}}$ and $\mathrm{C} 5-\mathrm{C} 13^{\mathrm{ii}}$. The distances are 3.210(11) and $3.369(11) \AA$, respectively (symmetry codes i: $1-x,-y,-z$ ii: $2-$ $\mathrm{x},-\mathrm{y},-\mathrm{z})$. The molecules in the crystal structure are stacked along the a-axis as shown Fig. (3b).
Table 5. Dihedral Angles Between the Least-Squares Planes of Rings

\begin{tabular}{|c|c|c|}
\hline Ring No & Ring No & Dihedral Angle ( ${ }^{\circ}$ ) \\
\hline \hline R1 & R2 & 12.36 \\
\hline R1 & R3 & 12.13 \\
\hline R1 & R4 & 2.98 \\
\hline R2 & R3 & 23.92 \\
\hline R2 & R4 & 10.51 \\
\hline R3 & R4 & 14.95 \\
\hline
\end{tabular}




\section{APPENDIX A. SUPPLEMENTARY DATA}

CCDC contains the supplementary crystallographic data 742262. These data can be obtained free of charge via http://www.ccdc.cam.ac.uk/conts/retrieving.html, or from the Cambridge Crystallographic Data Centre, 12 Union Road, Cambridge CB2 1EZ, UK; fax: (+44) 1223-336-033; or e-mail: deposit@ccdc.cam.ac.uk.

\section{REFERENCES}

[1] Lewis JW, Sandorfy C. Infrared absorption and resonance raman scattering of photochromic triphenylformazans. Can J Chem 1983; 61: 809-16.

[2] Katritzky AR, Belyakov SA, Cheng D, Durst HD. Syntheses of formazans under phase-transfer conditions. Synthesis 1995; 5: 57781.

[3] Nuutinen JM, Romppanen R, Makinen S, Vainiotalo P. Gas-phase oxidation and reduction of some 1-(2-benzothiazolyl)-3,5-diphenyl formazans. Complex formation with transition metals under laser desorption ionization. J Am Soc Mass Spectrum 1999; 10(4): 33946.

[4] Tezcan H, Can S, Tezcan R. The synthesis and spectral properties determination of 3- substituted phenyl-1,5-diphenylformazans. Dyes Pigm 2002; 52(2): 121-27.

[5] Tezcan H, Uzluk E. The synthesis and spectral properties determination of 1,3- substituted phenyl-5-phenylformazans. Dyes Pigm 2007; 75(3): 633-40.
[6] Tezcan H, Ozkan N. Substituent effects on the spectral properties of some 3-substituted formazans. Dyes Pigm 2003; 56(2): $159-66$

[7] Stoe \& Cie: X-AREA [Computer Program] Version 1.18 Darmstadt: Data Collection and Cell Refinement Software 2002.

[8] Stoe \& Cie: X-RED32 [Computer Program] Version 1.04. Darmstadt: Data Reduction Software 2002.

[9] Sheldrick GM. A short history of SHELX. Acta Cryst A 2008; 64(1): 112-22.

[10] Farrugia LJ. WinGX, System of programs for solving, refining and analysing. J Appl Cryst 1999; 32: 837-8.

[11] Spek AL. Platon, program for molecular packing geometry. J Appl Cryst 2003; 36: 7-13.

[12] Farrugia LJ. Ortep, thermal ellipsoid plot program. J Appl Cryst 1997; 30: 565

[13] Macrae CF, Edgington PR, Mc Cabe P, et al. Mercury, program for crystal structure visualization and exploration. J Appl Cryst 2006; 39: 453-7.

(C) Tunç and Yıldırım; Licensee Bentham Open.

This is an open access article licensed under the terms of the Creative Commons Attribution Non-Commercial License (http://creativecommons.org/licenses/by$\mathrm{nc} / 3.0 /$ ) which permits unrestricted, non-commercial use, distribution and reproduction in any medium, provided the work is properly cited. 